\title{
Kritik Pemikiran Arab: Metode Dekonstruksi Mohammed Arkoun
}

\author{
Siti Rohmah Soekarba
}

\begin{abstract}
Aвstract Mohammed Arkoun is one of an international Islamic modern thinker that his thought comes into Islamic thinking discourses in Indonesia recently. His Islamic thought were influenced by the modern philosophy concepts such as "myths" of Paul Ricouer, postmodern concepts like 'discourse' and 'episteme', which were developed by Michel Foucault as well as 'deconstruction' of Jacques Derrida. If Derrida focused on deconstruction of a discourse as a final concept, on the other hand Arkoun insisted that 'deconstruction' must be followed by 'reconstruction'. Arkoun's reconstruction leaves the limitation, the rigidity and deviation from the past. Arkoun proposes two ways: firstly it is 'ijtihâd' and subsequently it is Islamic critical reason with the whole of critical meaning. In this research the method I used was library investigation. Based on the result I came into the conclusion that Arkoun loss the communication with the scholars in the Islamic world, particularly in the Middle East tradition. Since then, he applied the method of deconstruction that Islamic world percept it was going too far.
\end{abstract}

KEYWORDS Dekonstruksi, Arkoun, wacana, epistemologi, rekonstruksi.

Perubahan merupakan suatu keniscayaan dalam kehidupan manusia. Perkembangan pemikiran yang juga mengandaikan perkembangan nalar dapat dilihat sebagai suatu respons manusia atas perubahan itu sendiri. Dengan demikian, nalar bukanlah sebuah konsep yang tetap dan tidak berubah. Nalar berubah seiring dengan perkembangan alat berpikir, temuan nalar itu sendiri. Nalar yang digunakan pada masa lalu mungkin saja sudah tidak sesuai apabila digunakan untuk menjawab realitas masa kini. Begitu juga sebaliknya, nalar yang relevan pada saat ini bisa jadi tidak tepat apabila digunakan dalam konteks masa lampau. Dalam wacana pemikiran Arab modern, paling tidak ada tiga tipe dominan. Pertama, tipe transformatik yang mewakili para pemikir Arab yang secara radikal mengajukan proses transformasi masyarakat Arab-Muslim dari budaya tradisi-partriarkal ke masyarakat rasional dan ilmiah. Kedua, tipe pemikiran reformistik yang menggunakan metode dekonstruktif. Ketiga, tipe pemikiran ideal-totalistik yang memiliki ciri utama yaitu bersikap dan berpandangan idealis tentang ajaran Islam yang bersifat totalistik (Assyaukanie 1998: 61 -65). 
Metode dekonstruktif merupakan fenomena baru bagi pemikiran Arab kontemporer. Para pemikir dekonstruktif adalah para pemikir Arab yang dipengaruhi oleh gerakan (pasca-)strukturalisme Prancis dan beberapa tokoh pascamodern lain, seperti Jacques Lacan, Roland Barthes, Michel Foucault, Jacques Derrida, dan Hans Georg Gadamer. Pemikir avant-garde dalam kelompok itu adalah Mohammed Arkoun dan Mohammed Abid Jabiri. Para pemikir lain yang sejalan dengan Arkoun dan Jabiri adalah M. Bennis, Abdul Kebir Khetibi, Salim Yafut, Aziz Azmeh, dan Hashim Shaleh.

Pemikiran Islam internasional yang masuk ke Indonesia pada akhirakhir ini banyak dikembangkan oleh Mohammed Arkoun (lahir tahun 1928), pemikir yang berasal dari Aljazair, yang menghabiskan sebagian hidupnya di Prancis. Ia adalah satu di antara sedikit pemikir Islam internasional mutakhir yang pemikirannya masuk ke dalam wacana pemikiran Islam di Indonesia. Arkoun memiliki keprihatinan yang mendalam atas perkembangan pemikiran Islam dewasa ini yang menurutnya beku, tertutup, dan dogmatis, yang menyuburkan fundamentalisme Islam. Menurutnya, hal itu disebabkan oleh redupnya warisan tradisi filsafat sehingga penerimaan tradisi Islam terjadi tanpa penelaahan kritis. Ia melihat perlunya metode kritik untuk membaca sejarah pemikiran Arab-Islam. Untuk itu, ia memanfaatkan pendekatan dan metodologi ilmu sosial dan konsep pascamodern seperti mitos dari Ricoeur, wacana (discourse) dan epistémé (système de pensée) yang dikembangkan Foucault, serta dekonstruksi yang dikemukakan Derrida. Metode dekonstruksi ini adalah salah satu dari metode yang digunakan Arkoun dalam memikirkan kembali Islam (Meleuman 1993: 9-103).

Menurut Arkoun, Islam bukanlah agama yang terorganisasi secara kaku dan dogmatis. Dalam perjalanan historisnya, melalui jalur kekuasaan, Islam telah menjadi dogma mati untuk kepentingan kekuasaan itu sendiri. Oleh karena itu, dari sudut pandang sejarah, pemikiran Islam telah mandek, terkotak-kotak, tertutup, sempit, dan logosentris.

Baginya, pemikiran Islam tidak lagi mau menerima perubahan dalam prosedur dan kegiatannya. Umat Islam harus mengakui bahwa selama empat abad pemikiran Islam tidak berdenyut sebagaimana pemikiran Eropa (Arkoun 1990a: 83). ${ }^{1}$ Pemikiran Islam hanya mengulang-ulang sikap akalreligius skolastik yang konservatif, sebagaimana yang digunakan selama Abad Pertengahan, tanpa bergeser sedikit pun dari posisi ini ke posisi modern (Arkoun 1990a: 83). ${ }^{2}$

Oleh karena itu, Arkoun mencanangkan sebuah proyek besar yang disebutnya "kritik nalar Islam" dan "pembukaan kembali pintu ijtihad". Dalam kenyataannya, ijtihad hanyalah memenuhi tuntutan ideologis dari penguasa. Oleh karena itu, ia mengusulkan agar tugas ijtihad diperluas lagi

${ }^{1}$ Tulisan ini merupakan hasil wawancara mendalam Hamid Basyaib dengan Arkoun ketika beliau berkunjung ke Yogyakarta untuk seminar tentang "Ekspresi Islam dalam Arsitektur".

2 "Profile de la Conscience Islamique", dalam Critique, hlm. 121:"... on peut dire que la pensée islamique <<orthodoxe>> s'en tient toujours à la répétition <<pieuse>> (le fameux taqlîd que les grands penseurs classiques ont condamné ou strictement limité à des domaines précis) de positions dogmatiques mises en place au Moyen Age". 
dengan usaha kritik nalar Islam (Arkoun dalam Nalar Islami, hlm. 54).

\section{Titik Sentral Pemikiran Arkoun}

Titik sentral pemikiran Arkoun terletak pada kata kunci kritik epistemologis. Istilah itu digunakan dalam berbagai karyanya meskipun dalam konteks yang berbeda-beda. Pemahaman dan makna kritik epistemologis dalam konsepsinya terasa lebih tajam, lantaran kritik epistemologis itu ditujukan pada bangunan "keilmuan" berbagai ilmu agama secara keseluruhan.

Sifat utama pemikiran Arkoun adalah penggabungan antara dunia Barat dan dunia Islam, sesuai dengan apa yang menjadi cita-citanya, yaitu pemaduan tertentu dari berbagai cara berpikir yang berbeda. Usaha pemaduan kedua unsur itu, unsur yang paling mulia dalam pemikiran islami (nalar islami) dan unsur yang paling berharga dalam pemikiran Barat yang modern (nalar modern), menjadi cita-cita yang melatarbelakangi segala kegiatan dan karyanya, yaitu pemaduan tertentu dari pelbagai cara berpikir yang berbeda.

Dasar epistemologi dan metodologi Arkoun diambil dari rasionalisme Descartes dan kritisisme Kant, strukturalisme de Saussure, semiotik Barthes, Hjemslev, dan Greimas serta "aliran Paris". Selain itu, konsep mitos dari Ricoeur, wacana (discourse) dan epistémé dari Foucault, dan dekonstruksi Derrida dimanfaatkan pula.

Pada Descartes dan Kant, teori kebenaran didasarkan pada aspek penalaran logis, konsisten, dan jelas berpusat pada subjek, bukan pada metode pengujian eksperimental. Kendati mengkritik logika empirisme-positivisme, Kant sesungguhnya sangat mengagumi kehebatan penalaran sesuai dengan logika yang memiliki kejelasan dan keruntutan dalam kerjanya. Oleh karena itu, dalam seluruh bangunan filsafatnya, Kant sangat dipengaruhi oleh formula bahasa logika. Contoh yang paling mencolok adalah etikanya yang terkenal dengan konsep categorical imperative. Di situ Kant berpendapat bahwa untuk mengetahui perbuatan baik dan dan buruk, sesungguhnya manusia tidak harus merujuk kepada Kitab Suci, tetapi cukup dengan menggunakan akal kritis dan akal praktis (Copleston 1968: 216-217). Bila kita mengamati kritik Arkoun terhadap bangunan Islam, tampaknya ia mengikuti logika Kant yang sebetulnya bertentangan dengan metode dekonstruksi.

De Saussure membuat perbedaan antara bahasa sebagai sistem (langue) dan bahasa sebagai wicara (parole). ${ }^{3}$ Wicara adalah sebuah peristiwa atau proses dan, karena itu, bersifat diakronis. Bahasa sebagai struktur adalah jaringan hubungan intern elemen bahasa sehingga bersifat sinkronis. Wicara bersifat individual dan intensional, sedangkan bahasa bersifat kolektif dan anonim. Arkoun mengajukan langkah membaca kembali wacana Islam agar

${ }^{3}$ Langue dan parole adalah istilah-istilah yang dikenal dalam disiplin semiotika. Istilah ini diperkenalkan pertama kali oleh Ferdinand de Saussure. Lihat antara lain dalam Roland Barhes, "Unsur-unsur Semiologi:Langue dan Parole" terj. Okke K.S. Zaimar, dalam Panuti Sudjiman dan Aart van Zoest, Serba-serbi Semiotika (Jakarta: Gramedia Pustaka Utama, 1996), hlm. $80-88$. 
Alquran tidak hanya menjadi bahasa, namun juga wicara bagi orang yang hidup pada zaman sekarang. Pada segi performatif (yang memiliki kekuatan kreatif), analisis simbolisnya itulah yang memungkinkan Surat al-Fâtihah menjadi wicara bagi siapa saja yang mengujarkannya.

Apabila ditelaah lebih jauh, ternyata hampir semua tafsir Alquran klasik cenderung pada konsep bahasa. Kelemahan penafsiran yang menekankan bahasa ini adalah terjadinya "pengeringan" makna Alquran dan fungsinya sebagai hidayah bagi kehidupan umat manusia. Arkoun menyebut tafsir jenis ini sebagai filologisme karena hanya terbatas pada aspek teks (Arkoun dalam Nalar Islami, hlm. 9).

Barthes mengikuti jejak Saussure dalam semiologi. Ia menggambarkan bahwa semiologi bertolak dari sistem dasar bahasa, yaitu bahasa dan wicara. Dua di antara dalil Saussure yang dikembangkannya adalah konsep tentang tanda dan tentang sifat tanda yang arbitrer dan konvensional. Menurutnya, manusia dalam ungkapan berbahasanya tidak langsung saja membicarakan "kenyataan", tetapi menggunakan berbagai tanda sesuai dengan aturan tertentu. Tanda itu, yang merupakan gabungan penanda dan petanda, dapat menjadi penanda dalam suatu sistem semiotis tingkat kedua, yang disebutnya mitos. Arkoun mengembangkan pendekatan mitos Barthes dan Ricoeur pada Alquran dan agama Islam. Ia meminjam ungkapan Ricoeur untuk melakukan semacam re-enactment pengalaman keagamaan pada analisis antropologis (mitis atau simbolis) ketika membaca Surat al-Fâtihah.

Ricoeur merumuskan mitos sebagai simbol sekunder yang membicarakan kenyataan manusia. Oleh karena itu, mitos bukanlah sesuatu yang harus ditinggalkan demi memodernkan pemikiran manusia. Yang harus ditinggalkan adalah penyalahgunaan mitos. Arkoun mengambil alih teori itu. Menurutnya, seperti juga berbagai kisah dalam Alkitab, wacana Alquran bersusunan mitis. Dalam keadaan sosial-historis, wacana Alquran berubah menjadi korpus tertutup.

Foucault memberikan pengertian tentang epistem (epistémé) sebagai cara memandang dan memahami kenyataan. Manusia pada tiap-tiap zaman menangkap kenyataan dengan cara tertentu. Oleh karena itu, manusia juga membicarakannnya dengan cara tertentu pula. Cara manusia membicarakan kenyataan itu disebutnya sebagai wacana. Foucault membagi tiga rentang epistem yang digunakan manusia Eropa: epistem zaman klasik, zaman tengah (Rennaissance), dan zaman pascaklasik. Arkoun mengadaptasi pemikiran Foucault dengan menerapkan konsep epistem pada pembagiannya atas tiga jenjang sejarah terbentuknya akal Arab-Islam: zaman klasik, zaman skolastik, dan zaman modern. Walaupun ia tidak mengambil alih semua pandangan filsafat Foucault, istilah epistem, wacana (discourse), dan arkeologi mendapat makna khusus darinya dan sering muncul dalam uraiannya.

Derrida mengetengahkan proses kritik dari dalam yang disebutnya "dekonstruksi" atau "pembongkaran". Proses pembongkaran yang mendapat perhatian khusus Derrida adalah "yang tak dipikirkan" dan "yang tak terpikir". Derrida mengatakan bahwa dekonstruksi menawarkan tekstualitas 
(écriture), meniadakan pengarang, mengalihkan sejarah dari tradisi ke dalam intertekstualitas, dan "merayakan" (celebrates) pembaca. Jadi, secara singkat dekonstruksi dapat dicirikan sebagai proses "kritik" dan "metakritik" spontan terhadap teks yang merupakan rajutan "jejak/bekas" (trace) untuk menafsirkan makna (maksud) yang "tercangkok" (grafted) antarrajutan jejak, tetapi tidak ada hasil penafsiran yang merupakan tafsiran akhir.

Jejak Derrida dalam pemikiran Arkoun juga sangat tebal. Logosentrisme, dekonstruksi (la déconstruction), "yang terpikirkan" (le pensable), dan "yang tak terpikirkan" (l'impensê) merupakan istilah yang dikembangkan Derrida dan sangat tampak dalam sejumlah tulisan Arkoun. Dalam uraiannya tentang nalar Islam, Arkoun selalu menekankan logosentrisme, dalam arti bahwa manusia tidak dapat berpikir di luar tradisi kebahasaan tertentu (adanya keterpusatan pada logos). Melalui pembongkaran teks Derrida, Arkoun berusaha menemukan kembali makna yang menjadi tersingkir atau terlupa akibat penutupan dan pembekuan yang dialami pemikiran Islam. ${ }^{4}$

\section{Pemikiran Dekonstruksi Arkoun}

Apabila kita membandingkan perkembangan nalar di Eropa dengan perkembangan nalar di dunia Arab atau Islam, akan tampak sekali kontras di antara keduanya. Perkembangan nalar yang sangat dinamis dan revolusioner-seperti yang terjadi di Italia, Prancis, Inggris, dan Spanyol semenjak abad ke-16 - tidak terjadi pada banyak masyarakat Arab atau Muslim. Kaum muslimin dapat dikatakan telah mengabaikan langkah besar yang dilakukan oleh nalar untuk terus mengupayakan otonominya dan meningkatkan fungsinya. Dari sudut pandang sejarah, pemikiran Islam dapat dikatakan telah mengalami stagnasi dalam arti tidak mau menerima berbagai macam perubahan. Semenjak abad ke-16 hingga kini pemikiran Islam boleh dibilang tidak berdenyut.

Berangkat dari kegusaran mandeknya pemikiran Islam, Arkoun kemudian mengajukan apa yang disebutnya sebagai "proyek kritik nalar Islam" yang terkandung dalam bukunya Pour une critique de la raison islamique (kritik nalar islami, 1984) dalam bahasa Prancis dan buku yang semula diterjemahkan ke dalam bahasa Arab menjadi Naqdu al-'Aqlîal-Islâmý, kemudian diterjemahkan menjadi Tarîkhiyah al-Fikr al-'Arabi al-Islâmi (historisisme pemikiran ArabIslam). Ia berfokus pada masalah pembacaan terhadap tradisi Arab-Islam. Tesis Arkoun berangkat dari masalah pembacaan sejarah atau problem historisisme dan masalah interpretasi (hermeneutik). Arkoun bermaksud melihat semua fenomena sosial budaya melalui perspektif sejarah, yaitu masa lalu harus dilihat tingkatan sejarahnya. Pencarian sejarah harus dibatasi

${ }^{4}$ Derrida selalu menekankan penolakannya pada logosentrisme atau keterpusatan pada logos. Pengertian logos dalam metafisika tidak hanya berarti 'kata', tetapi juga apakah dalam kesadaran dalam alam bisa disebut juga sebagai "kebenaran". Dengan adanya logosentrisme, dapat dikatakan bahawa tidak ada tempat Ego dalam filsafat Derrida. Lihat Christopher Norris dan Andrew Benjamin. What is Deconstruction (New York: Academy Edition:St. Martin's Press, 1988), hlm. 30-36. 
menurut runtutan kronologis dan fakta nyata. Artinya, penyejarahan berperan sebagai metode rekonstruksi makna melalui penghapusan relevansi antara teks dan konteks. Jika metode ini digunakan dalam berbagai teks agama, yang diperlukan adalah makna baru yang secara potensial bersembunyi di dalamnya (Arkoun 1987: 14).

Metode sejarah yang digunakan Arkoun adalah salah satu perpaduan dari beberapa ilmu sosial Barat modern yang direkayasa oleh para pemikir (pasca-) strukturalisme Prancis. Acuan utamanya adalah Saussure (linguistik), Levi-Strauss (antropologi), Lacan (psikologi), Barthes (semiologi), Foucault (epistemologi) dan Derrida (grammatologi). Semua unsur itu diolah sedemikian rupa sehingga menjadi "kritik nalar islami". Penelitian Arkoun atas teks klasik adalah untuk mencari makna lain yang tersembunyi di dalamnya sehingga, untuk menuju rekonstruksi (konteks), harus diadakan dekonstruksi (teks). Arkoun tidak hanya berhenti pada teks klasik peninggalan para ilmuwan dan sarjana Muslim, ia pun merambahi teks suci.

Bagaimana Arkoun melihat tradisi (turats)? Secara umum, ia membedakan dua bentuk tradisi. Dalam sejumlah karyanya yang ditulis dalam bahasa Prancis, ia menggunakan dua kata tradition dan turats secara bersama-sama dan membedakannya atas dua jenis: pertama, Tradisi atau Turats dengan huruf $T$ kapital, yaitu tradisi transenden yang selalu dipahami dan dipersepsikan sebagai tradisi ideal yang datang dari Tuhan dan tidak dapat diubah oleh kejadian sejarah. Tradisi semacam itu bersifat abadi dan absolut. Tradisi kedua ditulis dengan huruf $t$ kecil (tradisi atau turats), yang dibentuk oleh sejarah dan kebudayaan manusia, baik yang merupakan warisan turun-temurun sepanjang kehidupan, maupun penafsiran manusia atas wahyu Tuhan melalui teks kitab suci (Arkoun 1987: 17-24).

Dari kedua jenis tradisi tersebut, Arkoun menepikan jenis yang pertama. Menurutnya, tradisi itu berada di luar pengetahuan dan kapasitas akal manusia. Dengan demikian, target dan objek kajian yang dipilihnya adalah tradisi jenis yang kedua, yaitu yang dibentuk oleh kondisi sejarah (ruang dan waktu).

Membaca turats adalah membaca teks, semua jenis teks. Karena dibentuk dan dibakukan dalam sejarah, turats tersebut harus dibaca melalui kerangka sejarah. Baginya, salah satu tujuan membaca teks, khususnya teks suci, adalah untuk menghargainya di tengah perubahan yang terus terjadi. Artinya, berbagai ajaran agama yang berasal dari teks suci harus selalu sesuai dan tidak bertentangan dengan segala keadaan. Di sini tampak bahwa apa yang sedang diupayakan Arkoun adalah pengharmonisan tradisi dengan modernitas melalui metode baru.

Dewasa ini telah banyak pemerhati Alquran yang melakukan kritik historis dan linguistis yang menjadi ciri khas hermeneutik. Tulisan yang menyangkut bidang ini banyak bermunculan, baik dari kalangan orientalis maupun dari kalangan umat Islam sendiri. Mc Aucliffe (1988: 46-62) menulis "Qur'anic Hermeneutic: The Views of al-Tabari and Ibn Katsir" yang menekankan pada metode tafsirnya dan sedikit pada horizon sosialnya. 
Sarjana muslim kontemporer, Fazlur Rahman membahasnya dengan penafsiran double-movement, sementara Arkoun dengan lingkaran bahasapemikiran-sejarahnya.

Bagi Arkoun, penafsiran yang utuh melihat keterkaitan dimensi bahasapemikiran dan sejarah. Untuk menjalankan penafsiran yang hermeneutis ini, untuk Arkoun jalan pertama yang harus ditempuh adalah dengan memilah dan menunjukkan mana teks pertama atau teks pembentuk dan mana teks hermeneutis. Arkoun ingin mengembalikan pemikiran Islam ke wacana Alquran seperti sediakala yang terbuka terhadap berbagai pembacaan dan dengan demikian terbuka pula terhadap berbagai pemahaman.

Kesulitan yang dirasakan Arkoun dalam proyeknya ini adalah ternyata Alquran sebagai teks pertama atau peristiwa pertama telah tertimbun sedemikian rupa oleh pemikiran Islam yang berwujud pelbagai macam literatur yang merupakan teks kedua atau teks hermeneutis. Timbunan itu sedemikian rupa sehingga menghalangi pembaca untuk memahami Alquran dalam keadaannya seperti sediakala (Arkoun 1990b: 232).

Untuk mengatasi hal itu, Arkoun meminjam metode "dekonstruksi" atau "pembongkaran" Derrida dan juga analisis arkeologis yang dipakai dalam ilmu benda purbakala. Dengan analisis arkeologis, diupayakan satu klarifikasi historis terhadap teks hermeneutis dari tradisi pemikiran tertentu, yaitu memperjelasnya dengan membersihkan "debu" ruang dan waktu yang menyelubunginya sehingga akan terlihat hubungan antara teks dari fase sejarah tertentu dan kontek sosial, generasi, serta gerakan pemikiran yang beragam dan berada dalam waktu yang sama (Arkoun 1990b: 233-234).

Di samping menunjukkan hubungan antara pemikiran dan sejarah, Arkoun juga menunjukkan hubungan yang tak terpisahkan antara pemikiran dan bahasa. Setiap pemikiran keislaman, di samping merupakan "cermin" dari dinamika pergumulan realitas sosiohistoris pada tititk sejarah tertentu, juga terumuskan, terkonsepsikan, dan terungkapkan dalam "bahasa" tertentu.

Apa yang dilakukan oleh Arkoun adalah contoh bagaimana "mengolah" Alquran dengan alat bantu hermeneutik. Tradisi hermeneutik memusatkan perhatian pada tiga aspek: teks, konteks, dan kontekstualisasi dalam sebuah lingkaran yang tidak terputus. Artinya, ketika seorang melakukan penggalian dan sekaligus "reproduksi" makna, ketiga aspek itu harus dilibatkan tanpa terputus. Ketika menggali makna teks, seseorang harus memperhatikan konteks tempat teks itu muncul dan bagaimana dipahami sehingga dapat melakukan pemaknaan kembali teks yang dimaksud dalam konteks yang berbeda.

Dalam hal ini, Arkoun memaparkan bahwa harus selalu ada keterkaitan antara bahasa, pemikiran, dan sejarah. Umat Islam, dan umat beragama pada umumnya, perlu menyadari sepenuhnya adanya hubungan dialektis di antara ketiganya. Tidak ada pemikiran keagamaan apa pun yang terlepas sama sekali dari bahasa dan sejarah. Dalam kaitan dengan Alquran, Arkoun menegaskan bahwa kitab suci kaum muslimin itu merupakan perkataan, fenomena bahasa, kebudayaan, dan keagamaan yang lahir dalam suasananya sendiri sehingga 
tidak akan melahirkan berbagai makna kecuali jika dimasukkan dalam konteksnya; dan pada gilirannya melahirkan satu penstrukturan kesadaran. Terlebih pada kenyataannya Alquran merupakan teks keagamaan yang dimaksudkan untuk dibaca dan dihayati.

Menurut hemat saya, karya Arkoun penting ditelaah terutama karena menawarkan suatu metodologi kritis. Untuk memahami karyanya, saya berupaya untuk memusatkan perhatian pada aspek dekonstruksi dari kajiannya atas teks Islam. Dengan pendekatannya yang kritis, ia berhasil menjelaskan bahwa sejarah pemikiran Islam dikuasai dua kecenderungan, yaitu untuk menyakralkan teks serta tradisi dan membongkar penyakralan itu. Pemikiran Islam membutuhkan interaksi antara universalisme dan pluralisme.

Krisis lembaga agama mengindikasikan secara kuat bahwa sampai sejauh ini agama cenderung hadir sebagai sosok yang otoriter. Pesan agama yang pada awal kehadirannya dalam sejarah lebih cenderung pada upaya pembebasan, hilang oleh proses historis yang mendistorsinya. Krisis itu timbul karena agama berubah menjadi sebuah "hierarki" kelembagaan, yang berkuasa adalah "wewenang" tertentu yang berhak berkata mengenai kebenaran, mengatasnamakan "otoritas mutlak", apakah itu atas nama Tuhan, pihak yang berkuasa, atau lainnya.

Ketika agama mengalami proses pelembagaan yang berlebihan, yang terjadi adalah pembungkaman kekayaan tafsir. Di luar tafsir resmi yang diakui oleh lembaga yang berwenang, mustahil untuk mengakui kebenaran tafsir lain. Kitab suci yang semula terbuka kepada semua tafsir berubah menjadi satu tafsir (monophonic exegesis). Jika demikian, kemudian lahir semacam lembaga inkuisisi (mihnah) pada masa al-Makmun untuk kasus Islam, atau pada masa Reformasi untuk kasus Kristen (Herdi SRS dan Ulil-Abshor-Abdalla 1994: 84-85).

Hal itu menunjukkan bahwa ketika telah menjadi sebuah lembaga yang dimonopoli oleh otoritas tertentu, agama akan kehilangan wataknya sebagai pembebas. Dampak lain dari penafsiran tunggal adalah kesulitan interpretasi baru dan segar. Itulah sebabnya, tafsir ulang yang baru dan segar serta kontekstual dengan perkembangan zaman dan masyarakatnya menjadi keharusan. Hanya dengan reinterpretasi yang kontekstual dan terus-menerus, agama akan terbuka bagi perubahan zaman dan pembaruan serta terhindar dari otoriterisme yang memandulkan masyarakatnya sendiri.

Dominasi sebuah diskursus keagamaan atas diskursus keagamaan lain mengandaikan adanya sebuah struktur hierarkis penafsiran yang menempatkan diskursus keagamaan yang dominan itu pada posisi "pusat" dan menempatkan diskursus keagamaan lain yang ditundukkan pada posisi "pinggiran" (peripheri). Struktur hierarkis ini tidak hanya mengeksklusi diskursus keagamaan tertentu, namun juga menundukkan, menyubordinasikan, dan merepresinya (Alam 1994: 33).

Untuk itu, diperlukan suatu strategi untuk melakukan pembalikan struktur hierarkis penafsiran tersebut, untuk melakukan deligitimasi atas 
klaim "pusat", "origin", dan "primer" dari diskursus yang dominan. Strategi yang sangat bermanfaat untuk melakukan reinterpretasi atas proses pelembagaan agama yang berlebihan adalah metode dekonstruksi.

Dekonstruksi tidak merupakan sebuah diskursus, dalam artian sekumpulan pernyataan yang mengarahkan dan membentuk praktik-praktik itu. Dekonstruksi juga bukan berupa metode yang terdiri dari seperangkat aturan formal untuk menganalisis praktik-praktik diskursif dan nondiskursif (Culler 1987: 156). Dekonstruksi lebih merupakan sebuah strategi untuk memperlihatkan ambiguitas sebuah diskursus dengan jalan menelusuri gerakan-gerakan paradoksal yang terdapat di dalam diskursus itu sehingga tiap-tiap unit diskursus menyubversikan dasar-dasar asumsi yang dimilikinya sendiri.

Ambiguitas yang terdapat di dalam teks dan interpretasi atas teks terkait dengan persoalan makna dalam hubungannya dengan teks. Teks, menurut Derrida tidak memiliki makna literal, karena hal ini mengandaikan kehadirandiri (self-presence) yang absolut dari makna. ${ }^{5}$ Padahal, teks (penanda) sebagai sebuah representasi tidak pernah dapat menghadirkan ulang (representing) kehadiran dari makna (penanda) yang ditunjuk oleh teks tersebut (Young 1981: 15).

Teks berperan untuk membedakan (to differ) dan sekaligus menunda (to defer) sebuah makna. Dengan melakukan signifikasi (penandaan) pada sebuah makna, teks sekaligus menunjukkan ketidakhadiran sebuah makna lainnya. Namun, selanjutnya dengan melakukan penandaan pada sebuah makna, teks juga sekaligus menunda kehadiran makna tersebut; yang tersisa adalah "jejak" (trace) dari makna yang ditunjuk. Gerak tanda "membedakan" dan "menunda" ini yang disebut Derrida sebagai differance.

Dengan menekankan bahwa setiap teks (keagamaan) adalah "jejak" yang senantiasa menunjuk kepada teks-teks lainnya, sekaligus menegaskan penolakan atas klaim bahwa sebuah diskursus keagamaan dapat memiliki akses langsung kepada makna "asali" sebuah teks. Klaim inilah yang mengukuhkan posisi dominan sebuah diskursus atas diskursus lainnya. Dengan mengubah struktur hierarkis penafsiran, dekonstruksi menempatkan diskursus-diskursus dalam suatu posisi yang sejajar (co-existence).

Diskursus-diskursus keagamaan yang ditundukkan membentuk struktur resistensi bersama terhadap diskursus yang dominan. Dengan meruntuhkan struktur hierarkis yang mem-bentuk suatu hubungan dominasi-subordinasi,

${ }^{5}$ Pernyataan "there is nothing beyond the text" tidak secara otomatis menunjukkan bahwa Derrida menolak "realitas" di luar teks. Sebaliknya, realitas dipahami sebagai bagian dari teks. Penyempitan pengertian teks, misalnya, dilakukan Meuleman. Lihat, misalnya, J.H. Meuleman, "Nalar Islami dan Nalar Modern", dalam Jurnal Ulumul Qur 'an, No. 4, Vol. IV, Tahun 1993, hlm. 101, "...Ia (Derrida, pen.) menyatakan bahwa tidak ada acuan sama sekali di luar teks. Objek pembicaraan atau yang oleh filsuf terdahulu disebut "kenyataan", baru diciptakan oleh dan di dalam teks atau sehimpunan teks yang saling mempengaruhi. Derrida merumuskan hal itu dengan mengatakan bahwa tidak ada "petanda transendental". Artinya, tidak ada sesuatu di luar, di seberang sana teks. Jika anggapan Derrida itu diterapkan pada teks-teks wahyu, implikasinya menjadi bahwa tidak ada kebenaran ilahi, tidak ada Allah di belakang teks wahyu". 
diskursus-diskursus keagamaan yang ditundukkan dapat meruntuhkan peran legitimasi dan jastifikasi relasi-relasi kuasa represif yang ditopang oleh diskursus keagamaan yang dominan itu. Karena relasi kuasa tidak dapat bertahan tanpa ada diskursus yang menopangnya, maka relasi-relasi kuasa represif itu akan ditransformasikan menjadi relasi-relasi kuasa dalam bentuknya yang positif.

Penggunaan strategi dekonstruksi yang dikembangkan oleh Derrida secara komplementer di wilayah studi pemikiran Islam, dapat membentuk sebuah perspektif studi Islam yang kritis dan praktis. Kritis artinya ia melibatkan diri pada investigasi historis atas praktik-praktik keagamaan yang bersifat diskursif maupun sosial, guna menyingkap suatu wilayah bekerjanya relasirelasi kuasa. Adapun praktis berarti bahwa perspektif ini menyediakan suatu "ontologi historis" diri kita sendiri dalam suatu wilayah relasi-relasi kuasa, terutama untuk terlibat dalam perjuangan mentransformasikan bentuk-bentuk represif dari relasi kuasa-kuasa kepada bentuknya yang positif.

Dengan strategi dekonstruksi, perspektif ini tidak hanya menawarkan kepada kita suatu cara untuk membaca "teks", tetapi juga memberikan suatu arahan kepada suatu sikap, etos, dan prinsip saling mengakui serta menghargai keberadaan yang lain. Jika metode ini diterapkan ke dalam teksteks agama, maka pertama-tama yang harus dilakukan adalah memisahkan hubungan monolinier antara teks dan makna (tafsir)nya. Keyakinan bahwa ada hubungan yang final antara suatu teks dengan tafsir tertentu harus dibongkar. Hal itu karena keyakinan semacam itu akan menimbulkan dampak negatif. Pertama, fanatisme terhadap tafsir tertentu serta menolak kemungkinan keabsahan tafsir yang lain. Kedua, akan menutup kemungkinan terbukanya teks terhadap berbagai penafsiran. Dengan tertutupnya keragaman tafsir itu, sebuah teks akan mengalami semacam pembusukan. Ketiga, suatu teks yang telah dibekukan melalui peresmian satu tafsir saja akan menyebabkan teks itu tidak bermakna lagi dalam menghadapi derasnya perubahan sosial pada zaman modern dewasa ini (Herdi SRS dan Ulil-Abshor-Abdalla 1994: 87).

Dekonstruksi terhadap teks berarti membuka kemungkinan terhadap keragaman tafsir atas suatu teks. Dekonstruksi teks juga membawa konsekuensi lain yang lebih bersifat sosiologis, yakni membongkar monopoli tafsir pada otoritas tertentu yang berbicara mengenai "kebenaran tunggal" atas nama Tuhan, negara, atau penguasa. Dengan mengandaikan adanya otoritas tertentu, maka berarti juga mengandaikan "Aku-Transenden". Jika kita menepikan "Aku-Transenden" terbukalah berbagai kemungkinan untuk keragaman tafsir. Tafsir menjadi sesuatu yang relatif demokratis, sehingga kebenaran tidak menjadi monopoli satu tafsir tertentu.

Pemahaman mengenai kebenaran tunggal ini sebenarnya berkaitan dengan asumsi akan adanya "Aku-Transenden" yang mengetahui segalagalanya atas teks, sehingga tafsir yang diproduksinya memiliki "kewenangan tunggal" atas daerah kebenaran. Arkoun mendekonstruksi "Aku-Transenden" melalui konsep mengenai "historisitas logos" sehingga kewenangan tunggal itu kehilangan daya dukungnya sehingga muncullah alternatif pluralitas 
tafsir. Dalam konteks pluralisme itulah, hegemoni tafsir diruntuhkan dan teks menjadi hidup kembali serta terbuka atas semua tafsir. Dengan demikian, runtuh pula "pembekuan teks" pada agama dan ideologi yang menjadi awal mula dari kebekuan pemikiran selama ini. Kemungkinan untuk melakukan diskursus atas teks-teks keagamaan terkuak secara demokratis. Konsekuensi yang baik adalah kehidupan keagamaan umat manusia menjadi relatif lebih kritis, pluralistis, dan dinamis.

Arkoun memanfaatkan metode dekonstruksi ini untuk melakukan rekonstruksi kembali tradisi keilmuan klasik Islam. Dengan metode pembongkaran ini, akan terlihat lapisan-lapisan pengetahuan yang telah tertimbun oleh ortodoksi-ortodoksi, setelah itu diadakan pemilihan mana yang penting dan mana yang tidak penting dalam kajian Islam.

Studi elaboratif yang diajukan Arkoun agak berbeda dengan apa yang ditawarkan pemikir-pemikir Islam lainnya. Kecenderungan berpikir banyak diwarnai oleh strukturalisme, pascastrukturalisme, bahkan dekonstruksionisme yang memiliki gaya penitikberatan pada analisis linguistis. Dalam banyak karya ilmiahnya, Arkoun menggunakan tiga paradigma di atas untuk membaca dan memahami Islam dan juga, yang lebih penting lagi adalah untuk merumuskan kembali Islam.

Pantas dicatat bahwa dekonstruksi tidak mungkin dilakukan tanpa kesiapan pengetahuan akan sejarah, baik yang menyangkut tradisi Islam yang masih tersembunyi maupun tradisi yang sudah tercemar oleh unsurunsur luar. Dalam proses ini, Arkoun berusaha menekankan kembali makna yang menjadi tersingkir atau terlupa karena sekian banyak proses penutupan dan pembekuan yang dialami pemikiran Islam. Arkoun menegaskan bahwa dekonstruksi harus disertai dengan "rekonstruksi" suatu wacana yang meninggalkan keterbatasan, pembekuan, dan penyelewengan wacana sebelumnya.

Pencarian hubungan teks Islam dengan dekonstruksi dilakukan dengan mencari atau menjejaki teks-teks Derrida secara spesifik yang berkenaan dengan analisis pada teks Islam secara khusus. Arkoun berupaya membalikkan hierarki keutamaan dua konsep berpasangan. Membalikkan hierarki keutamaan dua konsep berpasangan adalah salah satu dari ciri dekonstruksi. Namun, berlawanan dengan Derrida, Arkoun tetap mempertahankan adanya suatu "petanda transendental". Ia berpendapat bahwa bahasa lisan adalah bentuk bahasa yang lebih awal dan lebih asli daripada bahasa tulis. Kemudian terjadilah peralihan dari bahasa lisan ke bahasa tulis, yang menandai sesuatu yang penting.

Arkoun berpendapat bahwa kita sepatutnya mengkritik model-model penalaran Islam tradisional yang mengacaukan interpretasi tradisional yang berakar pada sejarah dengan isi pewahyuan ilahi. Ia menyarankan kaum Muslim untuk mendekonstruksikan tata pikir masa lalu dan interpretasi atas teks-teks suci. Kebiasaan penalaran Islam yang diturunkan harus didekonstruksikan dan teks-teks suci harus terbuka terhadap penelitian historis dan linguistik modern. Karena itu, ia memanfaatkan metode dekonstruksi 
ini untuk melakukan rekonstruksi kembali tradisi keilmuan klasik Islam. Ia yakin bahwa tanpa rangsangan dan disiplin keterbukaan melalui pertemuan dengan hasil-hasil pemikiran modern, standar pengetahuan Islam di antara ulama tradisional dan para Islamis akan menurun.

Menurut Arkoun, jika dilihat dari sudut perkembangan filsafat kontemporer dan perubahan zaman yang disebabkan oleh berkembangnya ilmu pengetahuan sejak abad ke-16, sebenarnya studi Islam tidak dapat melepaskan diri dari pengaruh perkembangan ilmu pengetahuan dan perjumpaan budaya globat tersebut. Dalam studi Islam - jika saja istilah Islam diberi makna yang luas, yakni suatu bentuk respons filosofis terhadap perkembangan ilmu dan budaya-rumusan-rumusan yang dimunculkan masih terlalu jauh dari apa yang diharapkan. Ibaratnya, masih seperti air dan minyak. Dijauhinya pemikiran filosofis di lingkungan studi Islam, menurut Rahman merupakan intellectual suicide, sedangkan menurut Hassan Hanafi pemikiran Islam masih terlalu "terbelenggu" oleh teks sehingga kurang peka merespon realitas perkembangan zaman. Arkounlah yang tampaknya paling vokal mengkritik jantung pemikiran dan studi Islam. Dalam salah satu karyanya Arkoun menyatakan sebagai berikut.

...para ahli fikih yang sekaligus teolog (Kalam) tidak mengetahui hal itu. Mereka mempraktikkan jenis interpretasi terbatas dan membuat metodologi tertentu, yakni fikih dan perundang-undangan. Dua hal ini mengubah diskursus al-Qur'an yang mempunyai makna mitis-majazi, yang terbuka bagi berbagai makna dan pengertian, menjadi diskursus baku yang kaku ... telah menyebabkan diabaikannya historisitas norma-norma etikakeagamaan dan hukum-hukum fikih. Jadilah norma-norma dan hukum-hukum fikih itu seakan-akan berada di luar sejarah dan di luar kemestian sosial; menjadi suci; tidak boleh disentuh dan didiskusikan ... Para ahli fikih telah mengubah fenomena-fenomena sosio-historis yang temporal dan bersifat kekinian menjadi semacam ukuran-ukuran ideal dan hukum transenden yang kudus/suci, yang tak dapat diubah dan tak dapat diganti. Semua bentuk kemapanan dan praktik yang lahir dari hukum-hukum dan ukuran-ukuran ini kemudian mendapat aarde (ardiyyah) pengkudusan/pensakralan dan transendensi ketuhanan yang mencabutnya dari fondasi atau dari persyaratan-persyaratan biologis, sosial, ekonomi dan ideologis. Demikianlah, historisitas diabaikan dan dibuang oleh ortodoksi yang mapan. Keadaan seperti itu berlangsung terus sampai hari ini, bahkan pembuangan historisitas itu menjadi bertambah-tambah dengan perjalanan waktu. (Arkoun, terj. Hashim Saleh, 1990c: 124)

\section{Evaluasi Kritis terhadap Pemikiran Arkoun dan Relevansi Kajian}

Sebagai seorang pemikir pascamodernis, Arkoun memiliki pandanganpandangan yang sangat sulit dicerna, apalagi epistemologinya. Untuk memahami pemikirannya secara menyeluruh, kita perlu mendalami ilmu pengetahuan mutakhir yang berkembang terutama di Prancis, seperti linguistik, antropologi, semiotika, serta pelbagai gagasan dan pendekatan wacana pascamodernis yang sangat diakrabi oleh Arkoun.

Arkoun menggunakan bahasa yang rumit dalam karyanya. Seperti dikemukakannya sendiri, hampir mustahil mengungkapkan gagasan dalam bahasa bangsa yang belum memikirkannya. Dalam hal ini, Arkoun mengikuti tradisi Prancis tertentu. Salah satu aspek dari kesulitan bahasa Arkoun 
adalah kecenderungannya menggunakan aneka istilah dan ungkapan tanpa rumusan yang jelas atau dalam berbagai arti yang berbeda. Hal itu antara lain disebabkan banyaknya sumber rujukan yang digunakan secara variatif (Meuleman 1996: 153-154).

Derrida memberikan pengaruh yang sangat jelas kepada Arkoun. Ia sering menjadikan daerah "yang tak terpikirkan" (l'impense) dan "yang tak terpikir" (l'impensable) sebagai sasaran analisisnya. Ia menjelaskan bahwa teks-teks karya pemikiran Islam yang klasik lahir dari kebudayaan dan cara pemikiran tertentu dan pada gilirannya memperkuatnya. Dengan proses pembongkaran Derrida, Arkoun berusaha menemukan kembali makna yang menjadi tersingkir atau terlupa karena sekian banyak proses penutupan dan pembekuan yang dialami pemikiran Islam.

Kendati begitu banyak mengacu kepada Derrida, Arkoun mempunyai pendirian yang sangat bertentangan dengan dua visi Derrida. Pertama, Derrida meradikalkan pandangan adanya suatu "benda" dalam "kenyataan", yaitu di luar teks. Derrida menyatakan bahwa tidak ada acuan sama sekali di luar teks. Objek pembicaraan atau yang oleh filsuf terdahulu disebut "kenyataan", baru diciptakan oleh dan di dalam teks atau sehimpunan teks yang saling mempengaruhi. Kedua, Derrida merumuskan bahwa tidak ada "petanda transendental". Artinya, tidak ada sesuatu di luar, di seberang sana teks. Jika anggapan Derrida diterapkan pada teks-teks wahyu, implikasinya adalah bahwa tidak ada kebenaran ilahi, tidak ada Allah di belakang teks wahyu.

Arkoun menyangkal pemikiran Derrida di atas. Terhadap pendapat Derrida yang pertama, ia menyatakan bahwa wacana Alquran kemudian menjadi tertutup dan beku dalam korpus resmi tertutup, lalu korpuskorpus tafsiran yang menghasilkan berbagai karya tafsir, fikih, dan teologi, berasal dari Kalam Allah-dalam hal ini, ia justru dipengaruhi antropolog Inggris, Jack Goody ; menurut Meuleman, Derrida membicarakan persoalan filosofis, sedangkan Goody membicarakan suatu persoalan antropologis. Pertentangan-pertentangan berlandaskan agama terletak pada tataran tanda-tanda kebahasaan, ritual, kesejarahan, dan kesenian yang mengacu pada Transendensi yang sama. Arkoun mengemukakan anggapan yang mengandung tiga unsur penting: pertama, ia menghubungkan proses pembekuan dan penutupan dalam penafsiran Alquran dengan pengalihannya dari bentuk lisan ke bentuk tertulis; kedua, ia beranggapan bahwa dalam pemikiran manusia terjadi peralihan dua cara pemakaian bahasa; ketiga, ia berpendapat bahwa bahasa lisan adalah bentuk bahasa yang lebih awal daripada bahasa tulis.

Arkoun mempermasalahkan proses pembekuan dalam penafsiran Alquran. Ia menganggap peralihan dari bentuk lisan ke bentuk tulis adalah unsur yang sangat penting. Pencatatan pemikiran manusia secara tertulis adalah salah satu faktor utama dari pembekuan. Dalam pemikiran manusia terjadilah peralihan dari kalam kenabian ke wacana pengajaran atau akademis. Kalam kenabian membicarakan situasi keberadaan, cinta kasih, hidup dan mati. Adapun wacana pengajaran memerikan dan menggolongkan menurut 
konsep kaku. Yang pertama bersifat terbuka pada konteks yang beraneka ragam. Yang kedua cenderung membekukan makna dalam penafsiran kaku yang menolak penafsiran lain. Sebagai hasil dari peralihan tersebut, "teks" menjadi "preteks" (dalih), yang sering hanya diulangi dan tidak dipikirkan secara mendalam dan yang berfungsi sebagai pengabsahan kekuasaan kelompok tertentu. Akhirnya, peralihan dari kalam kenabian ke wacana pengajaran dikaitkan Arkoun dengan peralihan dari bahasa lisan ke bahasa tulis. Dalam rangka itu, Arkoun berulang kali menulis bahwa bahasa lisan lebih awal dan lebih asli daripada bahasa tulis.

Derrida menggarisbawahi keutamaan bahasa tulis terhadap bahasa lisan dalam rangka menentang pendirian filsafat tradisional yang menekankan prioritas subjek (pemakai-pembicara, penulis, pendengar, pembaca-teks) terhadap teks dan prioritas petanda terhadap penanda. Namun, Arkoun mengaitkan persoalan filosofis di atas dengan persoalan antropologis yang beranggapan bahwa masyarakat berbahasa tulis muncul setelah masyarakat lisan.

Derrida menolak adanya "petanda terakhir". Bahasa, menurut Derrida, adalah metafora yang tidak mempunyai rujukan final. Makna muncul karena pertukaran metafora. Makna akan berubah ketika para pelakunya berubah. Makna selalu bersifat dinamis dan relasional. Oleh karena itu rujukannya bersifat tak terbatas. Terhadap pendapat Derrida yang kedua itu, Arkoun justru tidak menolak konsep "petanda transendental" atau "transenden terakhir", yang sangat bertentangan dengan anggapan Derrida. Untuk mencari petanda terakhir ini, Arkoun menempuh langkah membongkar Surat al-Fâtihah yang dibaca dengan metode yang diajukannya. Dengan menggunakan teori dekonstruksi teks ini, diharapkan akan terkuak dan terbongkar kerangka Islam. Setelah terlihat kerangka Islam, kita dapat melihat dan membedakan mana yang Islam dan mana yang bukan unsur Islam. Selain itu, dengan dekonstruksi teks kita juga dapat memasukkan hal-hal yang belum dipikirkan dan hal-hal yang tidak mungkin atau dilarang dipikirkan ke dalam Islam. Jika Derrida berhenti pada dekonstruksi, Arkoun menegaskan bahwa dekonstruki harus disertai dengan rekonstruksi (pembangunan kembali) suatu wacana yang meninggalkan keterbatasan, pembekuan, dan penyelewengan wacana sebelumnya. Melalui upaya dekonstruksi-konstruksi, pemistikan, pemitologisan, dan pengideologian ditiadakan dan pemitosan serta pengidean dipulihkan. Jalan yang ditempuh adalah, pertama, ijtihad; dan, kedua, kritik akal islami dengan seluruh makna kritik.

Untuk mencari petanda terakhir ini Arkoun menempuh dua langkah, yaitu eksplorasi historis dan eksplorasi antropologis. Untuk eksplorasi historis, ia memilih karya Fakhr ad-Din ar-Râzi untuk membaca kembali salah satu khazanah tafsir klasik dan mencari petanda terakhir di dalamnya. Lewat eksplorasi antropologis, ia ingin mencari petanda terakhir dengan teoriteori tentang mitos, yang memperlihatkan bagaimana bahasa dipakai dalam berbagai simbol, yang ditunjukkan oleh Surat al-Fâtihah yang dibaca dengan metode yang diajukannya (Sunardi 1996: 76-77). Tampaknya, ia-sadar 
atau tidak - berupaya mengkombinasikan pelbagai teori dalam melakukan pendekatan metodologisnya, yang hasilnya cukup membingungkan.

Evaluasi kritis yang bisa kita ajukan untuk Arkoun adalah bahwa ia ingin menjelajah ke mana-mana dalam merealisasikan proyeknya. Hal ini membingungkan para pemerhatinya, terutama para pemula. Pada saat yang bersamaan, ia tidak memikirkan masalah keterbatasannya sebagai kritikus Islam, di samping keterbatasan ruang dan waktu yang ia miliki.

Arkoun banyak sekali menerbitkan uraian metodologis dan epistemologis. Karya-karyanya dapat dianggap sebagai pekerjaan pengantar, tetapi belum menawarkan suatu teologi Islam yang baru. Sumbangan pemikirannya memang kontroversial bagi sebuah wacana internal Islam.

Kebanyakan tulisan Arkoun memusatkan perhatian pada berbagai teks dari tokoh klasik yang besar atau juga beberapa tokoh kontemporer yang mewakili tradisi besar tertentu. Di satu sisi, Arkoun melewati batas tradisi studi Islam karena banyak meminjam pelbagai unsur dari filsafat, ilmuilmu sosial, dan humaniora Barat yang belum diterapkan dalam studi Islam terdahulu.

Dekonstruksi terhadap teks berarti membuka kemungkinan terhadap keragaman tafsir atas suatu teks. Arkoun menerapkan pendekatan ini untuk membaca kembali wacana Islam. Langkah yang telah dilakukannya ini memberikan sum-bangan yang cukup penting dan membawa "suasana baru" bagi perkembangan pemikiran Islam di Indonesia, sebagai negara berpenduduk mayoritas muslim. Apa yang diupayakan Arkoun ini bisa diterapkan untuk melakukan rekonstruksi terhadap tradisi keilmuan pada berbagai bidang kajian dan studi agama lainnya (Kristen, Yahudi, Budha, dan Hindu).

Untuk menyatukan titik temu antarberbagai aliran dan agama, ia menyarankan untuk menghindari pencampuradukan antara "kebenaran sosiologis" (pendapat mayoritas masyarakat) dan "kebenaran yang benar" (perdebatan dan pergulatan jiwa). ${ }^{6}$ Satu-satunya jalan yang ditempuh adalah dengan cara ilmiah dan teknis.

\section{KeSIMPULAN}

Arkoun menemukan penyebab paling mendasar atas krisis dunia Islam, yakni redupnya warisan tradisi filsafat dan pemahaman terhadap Islam yang bersifat dogmatis tanpa penelaahan kritis sehingga perkembangan pemikiran Islam dewasa ini berada pada kebekuan, ketutupan, dan kejumudan.

Sementara itu, pascamodernisme di Barat, sebagaimana diajukan oleh Derrida dan Foucault, muncul sebagai kerangka analisis untuk mengkritik modernitas. Dengan menempatkan diri sebagai kritik, pascamodernisme berupaya menandingi modernisme, meskipun ia tidak menawarkan blue print untuk membangun sebuah masyarakat baru. Apa yang patut dihargai dari tawaran Derrida dan Foucault adalah konsistensi mereka menerapkan

6 "La vérite est le surgissement d'une évidence à l'intérieur de l'esprit par la confrontation de l'esprit avec les données du réel". 
sistem pemikiran relasional dalam karya-karya mereka.

Dengan mengikuti uraian Derrida dan Foucault, Arkoun membahas teksteks Islam terutama sebagai sekian banyak momentum dalam berbagai proses pembekuan, pembatasan, dan penutupan yang berlangsung selama sejarah pemikiran Islam. Dengan dekonstruksinya, ia berupaya menemukan kembali makna yang menjadi tersingkir karena sekian banyak proses penutupan dan pembekuan yang dialami pemikiran Islam.

Kendati Arkoun mendambakan agar Islam menjadi objek penelitian multidispliner, ia tetap menampakkan diri sebagai pengkaji pemikiran Islam. Karyanya memang sangat kaya akan rujukan teoretis, yang diambil dari sejumlah besar cabang ilmu pengetahuan Barat masa kini. Pada prinsipnya, kemajemukan rujukan itu adalah suatu hal yang positif. Namun, Arkoun ternyata tidak selalu sadar akan ketegangan antara pelbagai acuan itu ataupun antara unsur tertentu dari sumber rujukannya dan dari pendiriannya sendiri.

Suatu masalah lain mengenai karya Arkoun adalah bahwa banyak persoalan yang dikemukakan di dalamnya tidak terpecahkan. Ia tidak menjelaskan sejumlah hal yang dikemukakannya. Ia tidak menawarkan berbagai pemecahan dan doktrin tuntas dan siap pakai. Kita tidak akan puas dengan Arkoun jika kita mengharapkan hal itu darinya.

Kita memerlukan daya kritis yang tajam untuk memahami pemikiran Arkoun karena ia menggunakan metodologi berbagai ilmu sosial yang ada, baik sejarah, politik, psikologi, sosiologi, mitologi, filsafat, semantik maupun linguistik, untuk menelaah naskah-naskah dan teks-teks keagamaan Islam yang masih dianggap standar sampai sekarang.

Pemikiran-pemikiran yang dilontarkan Arkoun sangat canggih sehingga membutuhkan pemahaman yang bertahap untuk masuk ke pemikirannya. Selama ini untuk memahami seorang tokoh Islam seperti Abduh, kita hanya perlu memahami budaya Islam-Arab. Tetapi untuk seorang seperti Arkoun, tidak cukup hanya memahami budaya Islam-Arab, namun sekaligus harus memahami budaya Prancis dan seperangkat hasil-hasil metode ilmu-ilmu sosial masa kini dan filsafat.

Arkoun berada di pihak yang berusaha melakukan pembaruan dalam memahami Islam dengan memanfaatkan perkembangan ilmu pengetahuan sosial Barat modern, terutama kritik sejarah dan kritik sastra yang berkembang dalam tradisi intelektual Prancis dan Jerman. Keuntungan Arkoun yang tumbuh di negara Aljazair adalah kedekatannya pada tradisi Islam klasik dan sekaligus tradisi intelektual Prancis yang kuat dalam kritik sastra dan filsafat. Oleh karena itu pikiran-pikiran Arkoun sulit memperoleh apresiasi dan tanggapan yang dialogis di kalangan dunia Arab yang beraliran konservatif.

Ajakan Arkoun untuk menghadirkan kembali iklim wacana kenabian yang bersifat terbuka dan dinamis memang relevan bagi para sarjana muslim yang tinggal di Barat atau masyarakat kampus yang mendalami khazanah Islam dan perduli terhadap kritik paradigma teori yang didesakkan oleh tradisi intelektual Barat. Tetapi bagi masyarakat awam atau mereka yang 
tengah merasakan ketenangan dan makna hidup melalui pemahaman Islam yang mengajarkan serba kepastian tanpa banyak diskusi, pikiran-pikiran Arkoun akan dianggap bid'ah teologis. Oleh para aktivis organisasi massa Islam yang lebih mengutamakan segi pengamalan agama dan senang pada ideologi aktivisme, alih-alih mengakrabi karya-karya Arkoun yang sebagian besar karyanya masih dalam bahasa Prancis, mereka tentu lebih menyenangi karya-karya Maududi (pemikir Islam India, 1903-1979), Hasan al-Banna (tokoh pergerakan Mesir, 1906 - 1949), Ali Shariati (sosiolog Iran, 1933-1977), Sayyid Qutb (pemuka gerakan Islam militan Ikhwanul Muslimin di Mesir, 1906 - 1966) atau Ayatullah Khomeini (pemimpin revolusi Iran, 1900 - 1989), dan semacamnya (Hidayat 1996: 33).

Metodologi yang diajukannya menawarkan sumbangan yang berharga dalam mempersiapkan medan pembaruan. Proyeknya adalah sebagai upaya bersama-sama yang lebih bersifat "sambil jalan" daripada sebuah pernyataan sebuah pendirian yang final. Namun, yang disayangkan, Arkoun kurang masih kurang terkenal.

Ada beberapa alasan mengapa Arkoun kurang terkenal. Pertama, sebagai orang yang bekerja di pinggiran akademik Barat dan pinggiran Islam, sebagian besar karya awalnya muncul di jurnal dengan oplah yang terbatas. Dengan satu pengecualian, bukunya yang pertama merupakan kumpulan artikel. Kedua, metodologi yang dibangunnya sendiri banyak menggunakan terminologi sosial-ilmiah, dan risetnya mengenai tradisi Islam yang dilakukan dengan sangat hati-hati memerlukan detail di luar jangkauan pembaca umum. Seseorang perlu mengetahui literatur kontemporer dalam sains kemanusiaan dan perlu mengenal sejarah Islam serta perlunya mengetahui bahasa Prancis untuk mengapresiasi sebagian besar yang ditulis Arkoun (Lee 1994: viii).

Akhirnya, kesimpulan yang dapat ditarik adalah bahwa Arkoun telah kehilangan komunikasi dengan umat Islam di dunia Arab ataupun di Indonesia. Ia menawarkan pengetahuan yang berharga dan kontributif, namun pemikiran yang dikemukakannya melangkah jauh, sementara pemikiran umat Islam pada umumnya masih sangat terbatas. Menurut saya, tugas cara baru penggunaan nalar yang diajarkannnya ini bukan hanya ada di atas pundak Arkoun, melainkan memerlukan dukungan para intelektual Muslim lain.

Bila kita menerima bulat-bulat apa yang dilontarkannya, maka menurut hemat saya, usaha yang dibangun Arkoun telah menemui kegagalan, karena ia sendiri telah menganjurkan kepada kita untuk berbuat kritis terhadap apa saja, termasuk terhadap berbagai pemikiran yang dilontarkannya.

\section{$D_{\text {aftar }}$ Acuan}

Abdullah, M. Amin (1995), Falsafat Kalam di Era Postmodernisme. Yogyakarta: Pustaka Pelajar. Alam, Rudy Harisyah (1994), “Perspektif Pasca-Modernisme dalam Kajian Keagamaan”, dalam Jurnal Ulumul Qurian No. 1, Vol. V.

Arkoun, Mohammed (1987), Al-Fikr al-Islami:Qiraat al-Ilmiyyah, terjemahan Hashim Shaleh. Beirut: Markaz al-Inma' al-Qaumy.

(1990a), “Menuju Pendekatan Baru Islam”, dalam Jurnal Ulumul Qur`an No. 7 Vol. II: 83. 
Jakarta: LSAF.

(1990b), Al-Fikr al-Islamy:Naqd wa al-Ijtihad, terjemahan Hasyim Shalih. London: Dar asSaqi.

(1990c), Al-Islam:Al-Akhlaq wa al-Siyasah, terjemahan Hashim Saleh, Markaz al-inma' alqaumy, Beirut, 1990.

Assyaukanie, A. Luthfi (1998), “Tipologi dan Wacana Pemikiran Arab Kontemporer”, dalam Jurnal Paramadina, Vol. I, No. 1.

Barthes, Roland (1996), "Unsur-unsur Semiologi:Langue dan Parole", terjemahan Okke K.S. Zaimar, dalam Panuti Sudjiman dan Aart van Zoest, Serba-serbi Semiotika, hlm. 80-88. Jakarta : Gramedia Pustaka Utama.

Copleston, Frederick (1968), A History of Philosophy Vol. VI. Wolf to Kant. London: Burn and Oats lmt.

Culler, Jonathan (1987), On Deconstruction:Theory and Criticism after Structuralism. London: Routledge and Kegan Paul, Ltd..

Herdi SRS dan Ulil-Abshor-Abdalla (1994), "Meruntuhkan Hegemoni Tafsir, Menghidupkan Kembali Teks", dalam Jurnal Ulumul Qur'an No. 3, Vol. V.

Hidayat, Komaruddin (1996) "Arkoun dan Tradisi Hermeneutika", dalam Johan Hendrik Meuleman (ed.), Tradisi, Kemodernan dan Metamodernisme. Yogyakarta: LKiS.

Lee, Robert D. (1994), "Forewords", dalam Rethinking Islam:Common Questions, Uncommon Answers. Oxford: Westview Press.

Mc. Mauliffe, Jane (1988), "Qur'anic Hermeneutics:The Views of al-Tabari and the Ibn Katsir", dalam A. Rippin (ed.), Approche to the History of the Qur'an, hlm. 46-62. Oxford: Clarendon.

Meuleman, Johan Hendrik (1993), “Nalar Islami dan Nalar Modern: Memperkenalkan Pemikiran Mohammed Arkoun", dalam Jurnal Ulumul Qur'an, No. 4 Vol. IV: 9-103. (1996), “Beberapa Catatan Kritis tentang Karya Mohammed Arkoun”, dalam Johan Hendrik Meuleman (ed.), Tradisi, Kemodernan dan Metamodernisme. Yogyakarta: LKiS.

Norris, Christopher dan Andrew Benjamin (1988), What is Deconstruction. New York: Academy Edition: St. Martin's Press.

Sunardi, St. (1996), “Membaca Quran bersama Mohammed Arkoun”, dalam Johan Hendrik Meuleman (ed.), Tradisi, Kemodernan dan Metamodernisme. Yogyakarta: LKiS.

Tarikhiyah al-Fikr al-Islami (1986). Beirut.

Young, Robert (1981), "Poststructuralism: An Introduction”, dalam Robert Young (ed.), Unitying the Text: A Post-Structuralism Reader. Boston: Routledge \&Kegan Paul Ltd. 